\title{
Evaluation of cytotoxicity of 5-n-alkylresorcinol homologs and fraction on mouse fibroblast cell line L929
}

\author{
Izabela Biskup $^{1} \cdot$ Ewa Zaczynska $^{2} \cdot$ Miroslawa Krauze-Baranowska $^{3} \cdot$ Izabela Fecka $^{1}$
}

Received: 27 July 2016 / Revised: 28 October 2016 / Accepted: 26 November 2016 / Published online: 9 December 2016

(C) The Author(s) 2016. This article is published with open access at Springerlink.com

\begin{abstract}
Cytotoxic effect of natural 5- $n$-alkylresorcinol fraction, individual homologs and some related compounds (resorcinol, orcinol and olivetol) was tested in vitro against mouse fibroblast cell line L929 in terms of their safety for use according to PN-EN ISO 10993-5:2009 method. Alkylresorcinol-rich fraction and five known individual alkylresorcinol homologs (C17:0, C19:0 C21:0, C23:0 and C25:0) were obtained from spelt (Triticum spelta L.) bran. The structures of these compounds were elucidated and confirmed by using two spectroscopic techniques: MS and NMR. Hydroquinone, positional isomer of resorcinol, was used as cytotoxic positive control. Cytotoxicity was expressed as $\mathrm{IC}_{50}$ and was estimated in the range of 171$2142 \mu \mathrm{M}$ for individual homologs depending on alkyl chain length. Alkylresorcinol-rich fraction, individual homologs, orcinol and olivetol exhibited cytotoxicity lower than hydroquinone but higher than resorcinol on normal cells. The highest cytotoxicity among isolated compounds was evaluated for C17:0. Structure-activity relationship was dose dependent and can be described by quadratic function. This study extends our knowledge about potential safety of use of alkylresorcinols in diet supplements, cosmetics or pharmaceutical products.
\end{abstract}

Izabela Biskup

izabela.biskup@umed.wroc.pl

1 Department of Pharmacognosy, Faculty of Pharmacy, Wroclaw Medical University, Borowska 211 A, 50-556 Wroclaw, Poland

2 Laboratory of Immunobiology, Institute of Immunology and Experimental Therapy, Polish Academy of Science, Weigla 12, 53-114 Wroclaw, Poland

3 Department of Pharmacognosy, Faculty of Pharmacy with Subfaculty of Laboratory Medicine, Medical University of Gdansk, Hallera 107, 80-416 Gdansk, Poland
Keywords Alkylresorcinols $\cdot$ Resorcinol $\cdot$ Spelt $\cdot$ Cytotoxicity

\section{Introduction}

Wheat (Triticum aestivum L.) from family Poaceae is the elementary cereal in the human diet in many countries. However, products from other cereal species from this family, e.g., spelt (Triticum spelta L.) or rye (Secale cereale L.), are becoming more and more popular. Whole-grain food is rich in fiber, vitamins, minerals, phytosterols and phenolics. Phenolic compounds are the most prevalent group of phytochemicals in plants. Among them are 5- $n$-alkylresorcinols (ARs). These compounds are localized in the outer layer (bran) and protect the kernel, e.g., from pathogens. Their content in bran is about $0.2 \%$ [1]. The high amounts of ARs are found in rye, wheat, triticale and barley. ARs have antibacterial, antifungal, antiparasitic properties and prevent from oxidative stress (proteins, lipids and DNA oxidation) occurring in many diseases [2]. Their antimutagenic properties were confirmed few years ago [3]. ARs fraction isolated from wheat bran inhibited $\alpha$-glucosidase in vitro, which may indicate that ARs may suppress postprandial blood glucose which is desired in type 2 diabetes management [4]. Wheat bran lipophilic extract containing ARs has also been proven to formulate nanoemulsion inhibiting tyrosinase activity involved in the browning of food products and melanosis in humans [5]. Previous studies on cereal ARs have evaluated them as active constituent in colon cancer prevention. Their antiproliferative activity was tested on human colon cancer cell lines HCT-116 and HT-29 [6, 7].

Separation of ARs from cereal source was usually performed by column chromatography combined with preparative HPLC and/or TLC [1, 6, 8]. Dey and Mikhailopulo 
optimized method of isolation of ARs from rye bran applying SFE extraction combined with prep-HPLC [9]. No attempt was undertaken to isolate ARs from spelt.

New possibilities for the use of ARs as active ingredients in diet supplements, cosmetics and pharmaceutical products are suggested [5]. For this reason, estimation of safe ARs level for normal cells is necessary. Fibroblasts are the most common type of cell found in connective tissue, e.g., skin. The aim of the study was to evaluate the cytotoxicity of ARs fraction and individual homologs on mouse fibroblast cell line L929. The evaluation of ARs cytotoxicity in comparison with structurally related compounds as hydroquinone and resorcinol, which had previously been used in pharmacy and cosmetic industry, is necessary step for development of their new applications.

\section{Materials and methods}

\section{Plant material}

Spelt (Triticum spelta L.) bran and rye (Secale cereale L.) bran were from Mlyny Wodne (Poland) purchased commercially available on Polish market.

\section{Solvents and chemicals}

Organic solvents and reagents used in the experimental section were of analytical grade. Acetonitrile and formic acid were from JT Baker (USA), whereas all other solvents (methanol, acetone, chloroform) were from Chempur (Poland). Water was glass-distilled and deionized. Methanol for UHPLC-ESI-MS was from Sigma-Aldrich (Poland). DMSO (dimethyl sulfoxide) was from SigmaAldrich (Poland). Silica gel (0.063-0.200 mm) was from Merck (Germany), while octadecyl Bakerbond $(40 \mu \mathrm{m})$ from JT Baker (USA).

\section{Standards and standard solutions}

Hydroquinone was from Fluka, Switzerland. Resorcinol, orcinol and olivetol (ARs-related compounds) were from Sigma-Aldrich, USA. Stock standard solutions $(1 \mathrm{mg} / \mathrm{mL})$ were prepared by dissolving an accurate amount of individual compound in methanol and filtered through a $0.45-\mu \mathrm{m}$ membrane filter (Millipore, USA). The standards solutions were stored at $-18{ }^{\circ} \mathrm{C}$ and were brought to the room temperature before use.

\section{Extraction and isolation by column chromatography}

Plant material ( $1 \mathrm{~kg}$ of spelt bran) was extracted with two solvents with different polarities. First, $70 \%$ methanol $(v / v)$ was used for extraction in ultrasound bath at temperature below $40{ }^{\circ} \mathrm{C}(5 \times 15 \mathrm{~min}$, in total $10.5 \mathrm{~L}$ of solvent $)$. Then, acetone $(5 \times 15 \mathrm{~min}, 10.5 \mathrm{~L})$ was used. Extraction was monitored by TLC on silica gel plates with mobile phase described later. All extracts were filtered, pooled according to solvent used for extraction and concentrated under reduced pressure at $40{ }^{\circ} \mathrm{C}$ (Büchi, Switzerland). $70 \%$ Methanolic extract was left for further different constituent isolation and analysis. Acetone extract (30.4 g) was chromatographed over silica gel column $(320 \times 40 \mathrm{~mm}, 200 \mathrm{~g})$. ARs were eluted with chloroform-acetone solvent gradient $(10+0,9.5+0.5,9+1,8+2,7+3,5+5,0+10$; $v / v)(250$ eluates, $50 \mathrm{~mL}$ each) which yielded 22 fractions (Ts1-Ts22) after TLC analyses. Ts1 to Ts8 were eluted with $(10+0)$, Ts9 to Ts14 with $(9.5+0.5)$, Ts $15(9+1)$, Ts16 to Ts19 with $(8+2)$, Ts20 with $(7+3)$, Ts21 with $(5+5)$ and Ts 22 with $(0+10)$. Fractions were concentrated under reduced pressure at $40{ }^{\circ} \mathrm{C}$. Fraction Ts11 (1.70 g, light beige powder), containing ARs mixture (ARTs), was dissolved in $10 \mathrm{~mL}$ of methanol in ultrasound bath at temperature below $40{ }^{\circ} \mathrm{C}$ and applied on octadecyl column $(40 \times 265 \mathrm{~mm}, 170 \mathrm{~g})$. Column was connected to vacuum pump and fractionated using methanol yielding 60 eluates $(50 \mathrm{~mL}$ each) which were combined together according to similar HPLC-PDA chromatographic profile to ten main subfractions (Ts11/1-Ts11/10) with C21:0 homolog $(573 \mathrm{mg})$ from Ts11/4, C23:0 homolog (116 mg) from Ts11/6 and C25:0 homolog (42 mg) from Ts11/8. Subfraction Ts11/2 (301 mg), with main compound C19:0 and admixture of C17:0, was left for further analyses. Fractions were crystallized from methanol at room temperature.

Another isolation (1 $\mathrm{kg}$ of rye bran) was performed again in the same manner with small modifications of solvent in order to compare their utilities for isolation. Acetone extract (32.8 g) was applied on silica gel column $(310 \times 60 \mathrm{~mm}, 220 \mathrm{~g})$ and eluted with petroleum etheracetone solvent gradient $(10+0,9.5+0.5,9+1,8+2$, $7+3,5+5,0+10 ; v / v)(254$ eluates, $50 \mathrm{~mL}$ each $)$ yielding 49 main fractions according to similar TLC chromatographic profile $(\mathrm{Sc} 1-\mathrm{Sc} 49)$. Sc1 was eluted with $(10+0)$, Sc2 to Sc10 with $(9.5+0.5), S c 11$ to Sc17 with $(9+1)$, Sc18 to Sc22 with $(8+2), \operatorname{Sc} 23$ to Sc25 with $(7+3), \operatorname{Sc} 26$ to Sc28 with $(5+5)$ and $S c 29$ to Sc49 with $(0+10)$. Fractions were concentrated under reduced pressure at $40{ }^{\circ} \mathrm{C}$. Sc15 (2 g), containing ARs mixture (AR-Sc), was used for further analysis. AR-Sc (light beige powder) was dissolved in $10 \mathrm{~mL}$ of methanol in ultrasound bath $\left(<40{ }^{\circ} \mathrm{C}\right)$ and applied on first octadecyl suspended in methanol column $(265 \times 40 \mathrm{~mm}, 140 \mathrm{~g})$. Column was connected to vacuum pump and fractionated using methanol yielding 168 eluates (10 $\mathrm{mL}$ each) which were combined together according to similar HPLC-PDA chromatographic profile to ten main subfractions (Sc15/1-Sc15/10). C21:0 homolog (403 mg) 


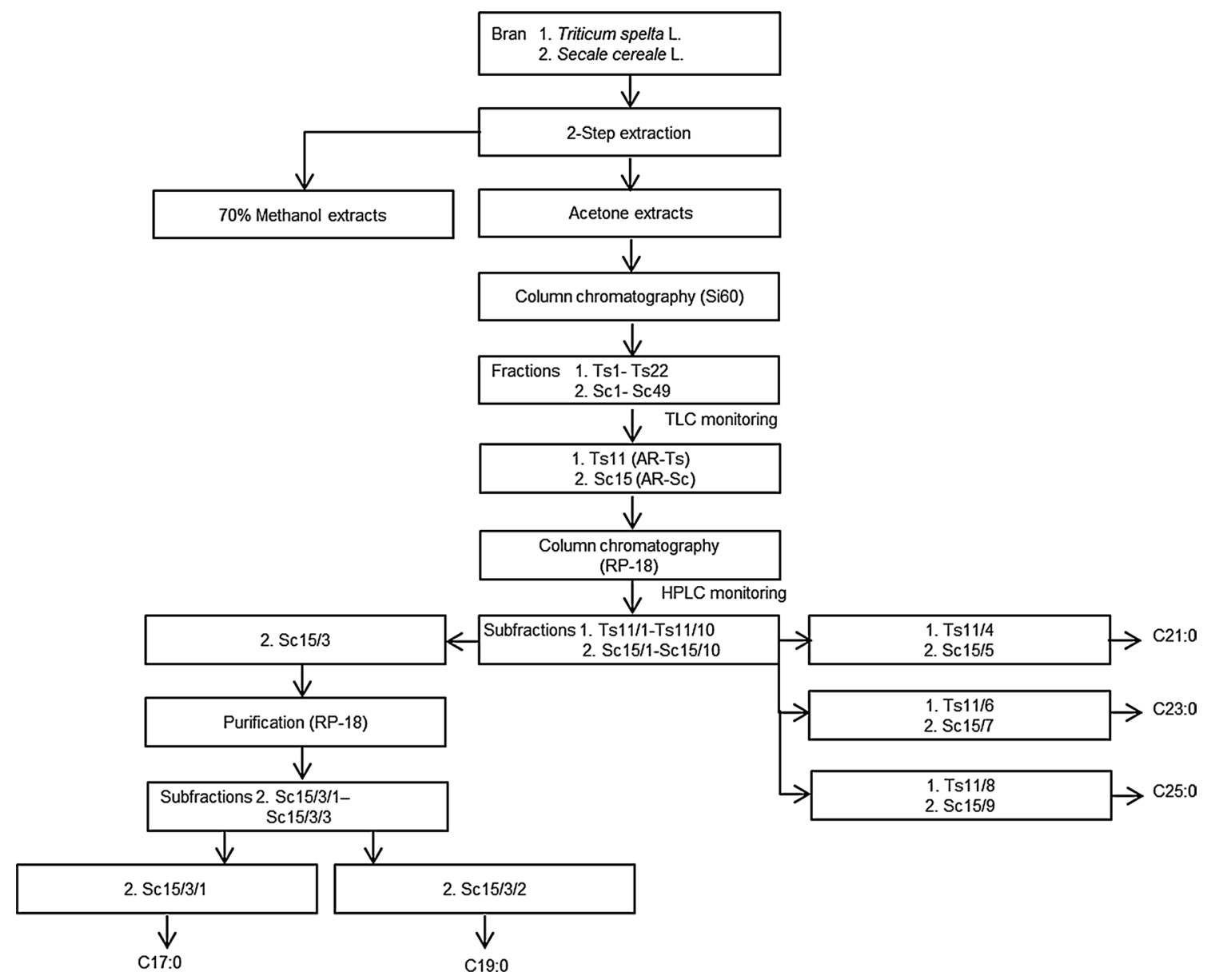

Fig. 1 Flowchart of ARs isolation from spelt and rye bran

was obtained from fraction Sc15/5, C23:0 homolog (169 mg) from fraction Sc15/7 and C25:0 homolog $(88 \mathrm{mg}$ ) from fraction Sc15/9. Subfraction Sc15/3 (1.0 g) was used for second octadecyl column $(375 \times 30 \mathrm{~mm}$, $128 \mathrm{~g})$ to separate alkylresorcinol single homologs C17:0 and C19:0. It was dissolved in $2 \mathrm{~mL}$ of methanol, applied on octadecyl and eluted with methanol-water solvent solutions $(9+1,9.5+0.5 ; v / v)$. Eluates $(206,10 \mathrm{~mL}$ each $)$ have been collected and combined together according to similar HPLC-PDA chromatographic profile to yield 3 subfractions with compound C17:0 (285 mg) from Sc15/3/1 and C19:0 (428 mg) from Sc15/3/2.

Process of isolation of ARs is depicted in flowchart (Fig. 1).

Structures of isolated compounds were confirmed on UHPLC-ESI-MS and NMR analyses.

\section{Chromatographic conditions}

HPLC-PDA analysis of alkylresorcinols for monitoring of isolation procedure was performed on the Smartline
Manager 5000 system version (Knauer, Germany) equipped with the Smartline Pump 1000, degasser, sample injector, column thermostat (Jetstream 2), Smartline PDA Detector 2800 and a Hypersil GOLD column $(250 \times 4.6 \mathrm{~mm}$ i.d., octadecyl $5 \mu \mathrm{m}$; Thermo Scientific, UK) with precolumn $(10 \times 4.5 \mathrm{~mm}$ i.d., octadecyl $5 \mu \mathrm{m}$; Thermo Scientific, UK). Detection was carried out using UV/Vis diode detector. The compounds were monitored at 202, 220 and $280 \mathrm{~nm}$, and UV spectra from 200 to $600 \mathrm{~nm}$ were recorded for peak characterization. Solvent solutions were vacuum degassed with ultrasonification prior to usage. Composition of mobile phases and profile of gradient for HPLC-PDA analyses were as follows: solvent A-water; solvent B-acetonitrile; commencing with $10 \% \mathrm{~B}$ in $\mathrm{A}$, rising to $70 \%$ after $25 \mathrm{~min}$ and then to $100 \%$ after $30 \mathrm{~min}$. Total run time was $55 \mathrm{~min}$. The flow rate was $1.3 \mathrm{~mL} / \mathrm{min}$. The injection volume was $20 \mu \mathrm{L}$. All HPLC-PDA experiments were performed at $22 \pm 2{ }^{\circ} \mathrm{C}$.

UHPLC-ESI-MS system (Shimadzu) equipped with Discovery HS C18 (Supelco) $7.5 \mathrm{~cm} \times 2.1 \mathrm{~mm} \times 3 \mu \mathrm{m}$ column operated at $30{ }^{\circ} \mathrm{C}$ was used for preliminary structure identification. The mobile phase consisted of methanol 
Table 1 Linearity parameters of HPLC-PDA method for ARs at $\lambda=280 \mathrm{~nm}(n=2 \times 11)$
Table 2 Repeatability parameters of HPLC-PDA method for ARs at $\lambda=280 \mathrm{~nm}$ $(n=6)$

\begin{tabular}{lllllll}
\hline Compound & Olivetol & C17:0 & C19:0 & C21:0 & C23:0 & C25:0 \\
\hline$a$ (slope) & 132 & 30 & 69 & 63 & 47 & 35 \\
$b$ (intercept) & 1 & 1 & 0 & 0 & 0 & 0 \\
$r$ (correlation coefficient) & 0.997 & 0.995 & 0.997 & 1.000 & 1.000 & 0.998 \\
Range $(\mathrm{mg} / \mathrm{mL})$ & $0.01-0.8$ & $0.01-1.0$ & $0.01-1.0$ & $0.01-1.0$ & $0.01-1.0$ & $0.01-1.0$ \\
LOD $(\mu \mathrm{g} / \mathrm{mL})$ & 2 & 10 & 4 & 5 & 6 & 9 \\
LOQ $(\mu \mathrm{g} / \mathrm{mL})$ & 675 & 33 & 15 & 16 & 21 & 29 \\
\hline
\end{tabular}

\begin{tabular}{lcccccr}
\hline Compound & Olivetol $^{\mathrm{a}}$ & $\mathrm{C} 17: 0^{\mathrm{b}}$ & $\mathrm{C} 19: 0^{\mathrm{b}}$ & $\mathrm{C} 21: 0^{\mathrm{b}}$ & $\mathrm{C} 23: 0^{\mathrm{b}}$ & $\mathrm{C} 25: 0^{\mathrm{b}}$ \\
\hline $\begin{array}{l}\text { Retention time } t_{\mathrm{R}} \\
(\min )\end{array}$ & 8.25 & 24.98 & 28.65 & 31.64 & 35.41 & 39.86 \\
$\mathrm{SD}$ & 0.23 & 0.67 & 0.76 & 1.36 & 1.29 & 0.93 \\
$\mathrm{CV}(\%)$ & 2.79 & 2.69 & 2.64 & 4.30 & 3.65 & 2.34 \\
Min (min) & 7.79 & 24.33 & 27.80 & 29.30 & 33.35 & 38.23 \\
Max (min) & 8.57 & 25.70 & 29.48 & 33.07 & 37.05 & 40.67 \\
\hline
\end{tabular}

${ }^{\text {a }}$ For olivetol at concentration $0.8 \mathrm{mg} / \mathrm{mL}$

${ }^{\mathrm{b}}$ For ARs homologs in AR-Ts fraction (eluent C) and water (eluent D), and the following gradient program was used: $10 \% \mathrm{C}$ in $\mathrm{D}(5 \mathrm{~min}), 47 \% \mathrm{C}$ in D (5 min), 85\% C in D (15 min), 100\% C (20 min). Total run time was $55 \mathrm{~min}$. The injection volume was $2 \mu \mathrm{L}$; total flow was $0.2 \mathrm{~mL} / \mathrm{min}$. ARs were monitored at 202, 220 and $280 \mathrm{~nm}$. In addition, UV-Vis spectra were recorded in the range $200-600 \mathrm{~nm}$. Molecules were detected on positive ion mode. Detector voltage was $1.2 \mathrm{kV}$, while interface voltage was $4 \mathrm{kV}$. Desolvation line and heat block temperature were 250 and $200{ }^{\circ} \mathrm{C}$, respectively. Nebulizing gas flow was $1.5 \mathrm{~mL} / \mathrm{min}$, drying gas flow was $16 \mathrm{~L} / \mathrm{min}$, and event time was $0.5 \mathrm{~s}$. Positive ion mass spectra were recorded in the range of $m / z, 100-500$ in SIM mode [10].

TLC analyses were carried out on $10 \times 20 \mathrm{~cm}$ silica gel plates Si60 (0.25 mm) obtained from Merck. Extracts, fractions from column chromatography and standard solutions were separated in mobile phase: chloroform-methanol-formic acid $(96: 3: 1 ; v / v / v)$ at a distance of $9 \mathrm{~cm}$. Chromatograms were developed in horizontal Teflon DS chambers (Chromdes, Poland). Colored compounds were detected as orange-red bands in visible light after spraying with visualizing reagent $(0.5 \mathrm{~mL}$ anise aldehyde, $10 \mathrm{~mL}$ acetic acid, $85 \mathrm{~mL}$ methanol, $0.5 \mathrm{~mL}$ sulfuric acid). All TLC procedures were performed at room temperature.

\section{Validation of HPLC-PDA method and quantitative measurement}

Measurements of ARs content in alkylresorcinol fraction (AR-Ts) were taken using HPLC-PDA and the external standards for calibration. Olivetol and isolated homologs were used for this purpose. Calibration equations for ARs were assessed at 11 concentration levels, and duplicate injections were performed for each concentration $(0.01$, $0.04,0.06,0.1,0.2,0.3,0.4,0.5,0.6,0.8$ and $1.0 \mathrm{mg} / \mathrm{mL}$ ). The linearity of standard curves was confirmed by plotting the peak areas $(y, \mathrm{mAU} / \mathrm{s})$ and the corresponding concentration $(x, \mathrm{mg} / \mathrm{mL})$. Limits of detection (LOD) and quantitation (LOQ) were calculated from calibration equations based on the signal-to-noise ratio ( $\mathrm{S} / \mathrm{N} \geq 3: 1$ and $\mathrm{S} / \mathrm{N} \geq 10: 1$, respectively) and expressed as the concentration of examined compound $(\mu \mathrm{g} / \mathrm{mL})$ in Table 1 . Repeatability and intermediate precision were calculated from retention time and peak areas, respectively. Olivetol $(0.8 \mathrm{mg} / \mathrm{mL})$ and AR-Ts $(1 \mathrm{mg} /$ $\mathrm{mL}$ ) were used for this purpose (Tables 2, 3).

The content of individual ARs (milligrams per gram or $\mu \mathrm{M})$ was estimated as the mean of three independent samples using the HPLC-PDA method. The sum of ARs was calculated as the sum of saturated homologs which were present in the analyzed fractions from their average values. Slope (a), intercept (b) and correlation coefficient (r) were also calculated.

\section{Structure elucidation of isolated alkylresorcinol homologs}

To assure the structures based on previously obtained MS data and to observe possible impurities, ${ }^{1} \mathrm{H}-,{ }^{13} \mathrm{C}-\mathrm{NMR}$, COSY and HSQC were measured for all compounds. 1D and 2D spectra were recorded on Avance II NMR apparatus 
Table 3 Intermediate precision parameters of HPLC-PDA method for ARs at $\lambda=280 \mathrm{~nm}$ $(n=6)$

\begin{tabular}{lrlrrrr}
\hline Compound & Olivetol $^{\mathrm{a}}$ & $\mathrm{C} 17: 0^{\mathrm{b}}$ & $\mathrm{C} 19: 0^{\mathrm{b}}$ & $\mathrm{C} 21: 0^{\mathrm{b}}$ & $\mathrm{C} 23: 0^{\mathrm{b}}$ & $\mathrm{C} 25: 0^{\mathrm{b}}$ \\
\hline Peak area $(\mathrm{mAU} \times \min )$ & 102.04 & 2.46 & 14.72 & 19.64 & 4.80 & 1.66 \\
$\mathrm{SD}$ & 3.53 & 0.10 & 0.52 & 0.65 & 0.21 & 0.09 \\
$\mathrm{CV}(\%)$ & 3.46 & 4.12 & 3.56 & 3.31 & 4.33 & 5.13 \\
Min $(\mathrm{mAU} \times \mathrm{min})$ & 99.55 & 2.27 & 14.19 & 19.01 & 4.64 & 1.54 \\
Max $(\mathrm{mAU} \times \mathrm{mi})$ & 104.54 & 2.54 & 15.43 & 20.52 & 5.19 & 1.76 \\
\hline
\end{tabular}

a For olivetol at concentration $0.8 \mathrm{mg} / \mathrm{mL}$

${ }^{\mathrm{b}}$ For ARs homologs in AR-Ts fraction

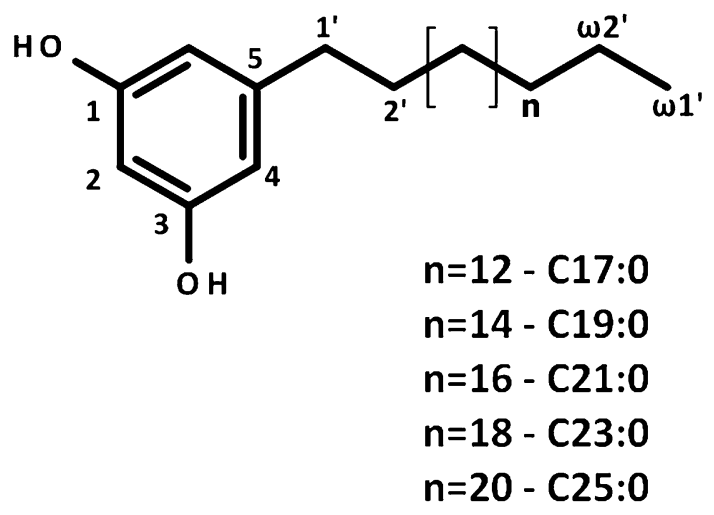

Fig. 2 Structures of ARs

(Bruker Biospin, Rheinstetten, Germany), with $300 \mathrm{MHz}$ for proton and $75 \mathrm{MHz}$ for carbon. Because of non-complete solubility of obtained compounds in $\mathrm{CDCl}_{3}$, samples were finally dissolved and measured in deuterated acetone and its internal signal was used as a standard for chemical shifts correction.

Spectra measured for all compounds were similar. Signals typical for 1,3-diphenol substituted with an aliphatic chain at C-5 position were clearly assigned: doubled singlet signal of two symmetrical protons at $6.94 \mathrm{ppm}(\mathrm{H}-4$ and H-6) correlated with carbon signal at $107.7 \mathrm{ppm}$ (C-4 and C-6), proton signal at $6.93 \mathrm{ppm}$ (s, H-2) correlated with $100.9 \mathrm{ppm}(\mathrm{C}-2)$, additionally - quaternary carbons signals at $159.3 \mathrm{ppm}$ (phenolic, doubled, C-1, C-3) and at 145.8 (C-5). Chain methylene signals were typically as follows: triplet at $3.19 \mathrm{ppm}$ (ring connected $\mathrm{H}-\mathrm{1}^{\prime}$, $J=7.5 \mathrm{~Hz}, 2 \mathrm{H})$ correlated with $36.6 \mathrm{ppm}\left(\mathrm{C}-1^{\prime}\right)$, multiplet at $2.31 \mathrm{ppm}\left(\mathrm{H}-2^{\prime}, 2 \mathrm{H}\right)$ correlated with $32.1 \mathrm{ppm}\left(\mathrm{C}-2^{\prime}\right)$, multiplet at $2.25-1.93 \mathrm{ppm}$ correlated with carbon signals at 31-28 ppm (unresolved, middle chain signals), $1.64 \mathrm{ppm}\left(\mathrm{H}-\omega 2^{\prime}, 2 \mathrm{H}\right)$ at $23.3 \mathrm{ppm}\left(\mathrm{C}-\omega 2^{\prime}\right)$ and methyl group signal of chain end at $1.64 \mathrm{ppm}\left(\mathrm{H}-\omega 1^{\prime}\right)$ correlated with $14.4 \mathrm{ppm}\left(\mathrm{C}-\omega 1^{\prime}\right)$. $\omega$ Indication was per analogy to fatty acids (Fig. 2). The experimental results were in good accordance with the literature data $[11,12]$ and predicted values.

\section{In vitro cytotoxicity test}

Mouse fibroblast cell line L929 was obtained from American Type Culture Collection (ATCC CCL-1). The cells were cultured in MEM (minimum essential medium Eagle) supplemented with $10 \%$ inactivated fetal bovine serum, $100 \mathrm{U} /$ $\mathrm{mL}$ penicillin, $100 \mu \mathrm{g} / \mathrm{mL}$ streptomycin and $2 \mathrm{mM} \mathrm{L-glu-}$ tamine at $37^{\circ} \mathrm{C}$, in a humidified atmosphere containing $5 \%$ $\mathrm{CO}_{2}$. All reagents, cell culture media and supplements used in cytotoxicity study were obtained from Sigma-Aldrich except MEM medium which was from IITD (Poland).

Cytotoxicity of AR-Ts, isolated homologs, compounds with related structures and hydroquinone (positional isomer of resorcinol), as positive control, were studied on mouse fibroblast cell line L929 according to standard method (PN-EN ISO 10993-5:2009). Tested compounds were dissolved in DMSO $(2500 \mu \mathrm{g} / \mathrm{mL})$, but serial dilutions (19.5$1250 \mu \mathrm{g} / \mathrm{mL}$ ) of each compound were prepared in the culture medium. Additionally, DMSO was also checked for toxicity by preparing serial dilution in medium and microscopic observation (Blank).

$100 \mu \mathrm{l}$ of $2 \times 10^{4}$ cells was seeded in 96-well plates (Nunc) and left for $24 \mathrm{~h}$. Then, $100 \mu \mathrm{l}$ various doses (ranged from 19.5 to $2500 \mu \mathrm{g} / \mathrm{mL}$ ) of tested compounds were added to the cells and cultivated for $72 \mathrm{~h}$ at $37{ }^{\circ} \mathrm{C}$ in air containing 5\% carbon dioxide and $95 \%$ humidity. Then, cultures were examined under microscope and pictures were taken. Cell growth, cell morphology and cell viability were used as parameters to determine the cytotoxicity of these substances. For cell viability, trypan blue staining assay was used. $10 \mu \mathrm{L}$ of a cell suspension was incubated at room temperature with $10 \mu \mathrm{L}$ of $0.4 \%$ trypan blue for $15 \mathrm{~min}$. Viability of the cells was measured in a Bürker chamber. Dead cells were navy blue and live cells remained unstained. The degeneration of cells was assessed using an inverted microscope at $400 \times$ magnification.

MTT assay was performed to determine $\mathrm{IC}_{50}$ (minimal concentration toxic to approximately $50 \%$ of cells). $25 \mu \mathrm{L}$ of MTT solution $(2 \mathrm{mg} / \mathrm{mL})$ was added to each well. After 3-h incubation, content was removed from wells and $80 \mu \mathrm{L}$ 
Fig. 3 HPLC-PDA chromatogram of $70 \%$ methanolic extract $(\lambda 280 \mathrm{~nm})$

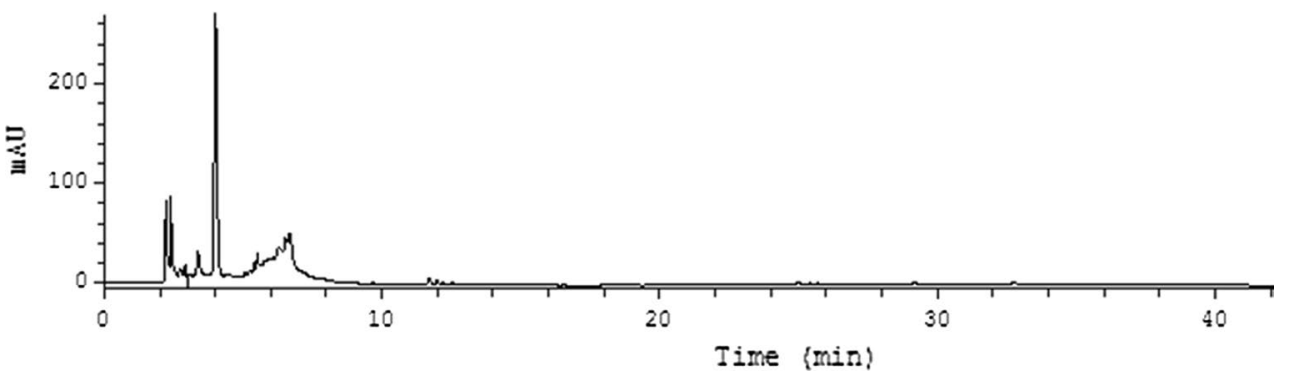

of saturated SDS solution was added to each well and shaken. Absorbance was read at $\lambda$ 550/630 nm. Viability of cells was calculated by dividing optical density of tested substance (ts) by control (c) and multiplying by $100 \%$ (viability $\left.\%=\mathrm{OD}_{\mathrm{ts}} / \mathrm{OD}_{\mathrm{c}} \times 100 \%\right) . \mathrm{IC}_{50}$ was calculated from concentration curve equation and was expressed as $\mu \mathrm{g} / \mathrm{mL}$ and $\mu \mathrm{M}$.

\section{Results and discussion}

The main saturated alkylresorcinol homologs of natural origin were isolated for biological tests. The following cereal bran was used: spelt for homologs C19:0 to C25:0 and rye for isolation of shorter chain homolog: C17:0 and also others. First, the two-step ultrasound-assisted extraction (UAE) with solvents of different polarities $(70 \%$ methanol and acetone) was carried out. Use of $70 \%$ methanol (first step) allowed the separation of more polar ballast compounds prior to ARs which were extracted with acetone (second step). ARs have been detected in traces amounts in $70 \%$ methanolic extract (Fig. 3). Usage of UAE shortens the extraction time compared to 24-h maceration protocol [1, 13]. Supercritical fluid extraction applied to separate ARs fraction described by Dey et al. and Athukorala et al. [8, 9] also accelerated the extraction process but requires advanced apparatus. Proposed simple two-step UAE method gave similar extraction yield in a similar duration time compared to SFE-about $2 \mathrm{~g}$ of ARs from $1 \mathrm{~kg}$ rye bran. An alternative way of obtaining ARs is chemical synthesis, e.g., by Grignard or alkyl-lithium methods. They are time-consuming and require special conditions and the yields vary. However, modification of Wittig reaction by microwaves use greatly improved the synthesis [14].

Acetone extracts from spelt and rye bran rich in ARs were subjected to series of column chromatography (Fig. 1). First, extracts were chromatographed over silica gel to afford alkylresorcinol fractions (AR-Ts from spelt and AR-Sc from rye) as light beige powders. ARs separation was performed twice with two different eluents in order to verify their utility: with increasing percentage of acetone in a nonpolar organic solvent (chloroform and petroleum ether for spelt and rye bran, respectively). Usage of chloroform with acetone accelerates separation compared to eluent composed of petroleum ether and acetone (22 vs. 49 fractions). The collected fractionations were monitored by TLC on silica gel plates. UHPLC-ESI-MS was used for preliminary identification of alkylresorcinols (Table 4) while HPLC-PDA for their quantification (Table 5; Fig. 4).

Then, AR-Ts (1.7 g) and AR-Sc (2 g) were chromatographed over octadecyl columns. Individual homologs: C17:0, C19:0, C21:0, C23:0 and C25:0 were eluted with methanol-water system and methanol. All steps were monitored with HPLC-PDA. The structures of isolated ARs were elucidated by ${ }^{1} \mathrm{H}-,{ }^{13} \mathrm{C}-\mathrm{NMR}, \mathrm{COSY}$ and HSQC and compared with the literature [11, 12]. 1D and 2D NMR spectra were used for structure confirmation. All spectra were almost identical; thus, only example (C21:0) is given here: ${ }^{13} \mathrm{C}$ NMR (75 MHz, acetone) $\delta 159.29(\mathrm{C}-1$, C-3), 145.84 (C-5), 107.69 (C-4, C-6), 100.91 (C-2), 36.60 $\left(\mathrm{C}-1^{\prime}\right), 32.08$ (C-2'), 31-28 (unres., chain), 23.33 (C- $\left.\omega 2^{\prime}\right)$, $14.36\left(\mathrm{C}-\omega 1^{\prime}\right)$ and ${ }^{1} \mathrm{H}$ NMR $(300 \mathrm{MHz}$, acetone) $\delta 6.94$ (H-4, H-6, 2H), 6.93 (H-2, 1H), $3.19\left(\mathrm{H}^{\prime} 1^{\prime}, t, J=7.5 \mathrm{~Hz}\right.$, 2H), 2.31 (H-2', m, 2H), 2.25-1.93 (chain), 1.64 (H- $\omega 1^{\prime}$, 3H) (Fig. 5).

The contents of main individual homologs and sum of them in AR-Ts were calculated and expressed as commonly used olivetol equivalents and as original compounds (Table 5). Chromatographic analyses of AR-Ts fraction (Tables 4,5 ) revealed 28 alkylresorcinols with five saturated homologs as major components, which constituted $86 \%$ mass weight $(2174 \mu \mathrm{M})$. Additionally, in small amounts, unsaturated alkylresorcinol homologs containing 1, 2 or 3 double bonds in alkyl chain (compounds 3, 6-8, 10-12, 14, 16-17, 19-22, 24, 26-27) and monounsaturated homologs with an additional $-\mathrm{OH}$ group in the alkyl chain (compounds 4-5, 9, 15) were identified (Table 4; Fig. 5) which is in agreement with literature data [10].

ARs have been suggested as foodstuff, cosmetic or pharmaceutical ingredients, and therefore, examination of their cytotoxicity on normal cells is essential. The cytotoxic activity of AR-Ts, isolated homologs and 
Table 4 Identification of ARs by UHPLC-ESI-MS

\begin{tabular}{|c|c|c|c|c|c|}
\hline Compound & $t_{\mathrm{R}}(\min )$ & $\lambda_{\max }(\mathrm{nm})$ & {$[\mathrm{M}+\mathrm{H}]^{+} m / z$} & $-\mathrm{R}$ (alkyl chain) & Identity \\
\hline Resorcinol & 3.6 & $199,218,273,281$ & 111 & $-\mathrm{H}$ & Standard \\
\hline Olivetol & 10.6 & $199,226,273,281$ & 181 & $\mathrm{C} 5: 0$ & Standard \\
\hline 1 & 12.8 & $199,232,273,281$ & 279 & unknown & Unknown \\
\hline 2 & 14.1 & $198,220,273,281$ & 321 & C15:0 & 5-n-Pentadecylresorcinol \\
\hline 3 & 14.7 & + & 371 & $\mathrm{C} 19: 3$ & Nonadecatrienylresorcinol \\
\hline 4 & 14.8 & + & 391 & $\mathrm{C} 19: 1 \mathrm{OH}$ & Hydroxynonadecenylresorcinol \\
\hline 5 & 15.8 & + & 363 & $\mathrm{C} 17: 1 \mathrm{OH}$ & Hydroxyheptadecenylresorcinol \\
\hline 6 & 16.0 & $198,217,262,281$ & 371 & $\mathrm{C} 19: 3$ & Nonadecatrienylresorcinol \\
\hline 7 & 16.2 & $198,219,262,280$ & 429 & $\mathrm{C} 23: 2$ & Tricosadienylresorcinol \\
\hline 8 & 19.0 & + & 371 & $\mathrm{C} 19: 3$ & Nonadecatrienylresorcinol \\
\hline 9 & 19.6 & $199,230,273,281$ & 391 & $\mathrm{C} 19: 1 \mathrm{OH}$ & Hydroxynonadecenylresorcinol \\
\hline 10 & 19.8 & $199,271,281$ & 347 & $\mathrm{C} 17: 1$ & Heptadecenylresorcinol \\
\hline 11 & 20.3 & $199,272,281$ & 373 & C19:2 & Nonadecadienylresorcinol \\
\hline 12 & 21.2 & + & 399 & $\mathrm{C} 21: 3$ & Heneicosatrienylresorcinol \\
\hline 13 & 21.8 & $199,223,274,281$ & 349 & C17:0 & 5-n-Heptadecylresorcinol \\
\hline 14 & 21.9 & $199,227,273,281$ & 431 & $\mathrm{C} 23: 1$ & Tricosenylresorcinol \\
\hline 15 & 22.0 & $199,224,274,281$ & 419 & $\mathrm{C} 21: 1 \mathrm{OH}$ & Hydroxyheneicosenylresorcinol \\
\hline 16 & 22.1 & $199,227,274,281$ & 459 & $\mathrm{C} 25: 1$ & Pentacosenylresorcinol \\
\hline 17 & 22.5 & $199,230,272,281$ & 401 & $\mathrm{C} 21: 2$ & Heneicosadienylresorcinol \\
\hline 18 & 23.9 & $199,224,274,282$ & 377 & C19:0 & 5-n-Nonadecylresorcinol \\
\hline 19 & 23.9 & $199,224,274,282$ & 399 & $\mathrm{C} 21: 3$ & Heneicosatrienylresorcinol \\
\hline 20 & 24.0 & $201,223,274,282$ & 431 & $\mathrm{C} 23: 1$ & Tricosenylresorcinol \\
\hline 21 & 24.1 & $199,223,274,281$ & 403 & $\mathrm{C} 21: 1$ & Heneicosenylresorcinol \\
\hline 22 & 24.3 & $199,230,274,281$ & 403 & $\mathrm{C} 21: 1$ & Heneicosenylresorcinol \\
\hline 23 & 25.9 & $199,223,274,281$ & 405 & C21:0 & 5-n-Heneicosylresorcinol \\
\hline 24 & 26.0 & $199,230,274,281$ & 431 & $\mathrm{C} 23: 1$ & Tricosenylresorcinol \\
\hline 25 & 27.6 & $199,223,274,281$ & 433 & C23:0 & 5-n-Tricosylresorcinol \\
\hline 26 & 27.6 & $199,223,274,281$ & 431 & $\mathrm{C} 23: 1$ & Tricosenylresorcinol \\
\hline 27 & 29.5 & $199,225,274,281$ & 431 & $\mathrm{C} 23: 1$ & Tricosenylresorcinol \\
\hline 28 & 29.5 & $199,225,274,281$ & 461 & C25:0 & 5-n-Pentacosylresorcinol \\
\hline
\end{tabular}

+ Present in very small amount; main compounds bolded

Table 5 Concentration of 5- $n$-alkylresorcinol homologs in AR-Ts

\begin{tabular}{lll}
\hline Compound & \multicolumn{2}{l}{ Concentration in $\mathrm{mg} / \mathrm{g}(\mu \mathrm{M})$} \\
\cline { 2 - 3 } & Olivetol eq. & Original compound \\
\hline $\mathrm{C} 17: 0$ & $7[37]$ & $56[162]$ \\
$\mathrm{C} 19: 0$ & $139[773]$ & $287[763]$ \\
$\mathrm{C} 21: 0$ & $168[931]$ & $372[921]$ \\
$\mathrm{C} 23: 0$ & $25[141]$ & $103[239]$ \\
$\mathrm{C} 25: 0$ & $1[4]$ & $42[89]$ \\
Sum & $340[1886]$ & $860[2174]$ \\
\hline
\end{tabular}

related compounds such as resorcinol, orcinol and olivetol were tested by reference method in mouse fibroblast cell line L929 (PN-EN ISO 10993-5:2009). DMSO was also checked for toxicity by preparing its serial dilution in medium and microscopic observation (Blank).

Hydroquinone was used as a cytotoxic positive control. Hydroquinone has been used in skin-lightening products for almost 50 years. Many ambivalent opinions have been attributed to this compound because of its cytotoxicity. Nowadays, only prescription-based medications with hydroquinone are allowed in EU [15]. In our experiment, hydroquinone inhibited cell growth completely at all concentrations. No agglutination, vacuolization, separation from the medium or cell membrane lyses were observed for cell control or blank (Fig. 6a). The cell culture after contact with all compounds up to $39 \mu \mathrm{g} / \mathrm{mL}$ also showed good proliferation and no toxic effect (Fig. 6b). Cells were damaged and dead after the contact with tested substances at different concentrations depending on structure (Fig. 6c). 
Fig. 4 HPLC-PDA chromatogram of alkylresorcinol fractions ( $\lambda 280 \mathrm{~nm})$ : AR-Ts (upper) and AR-Sc (lower)

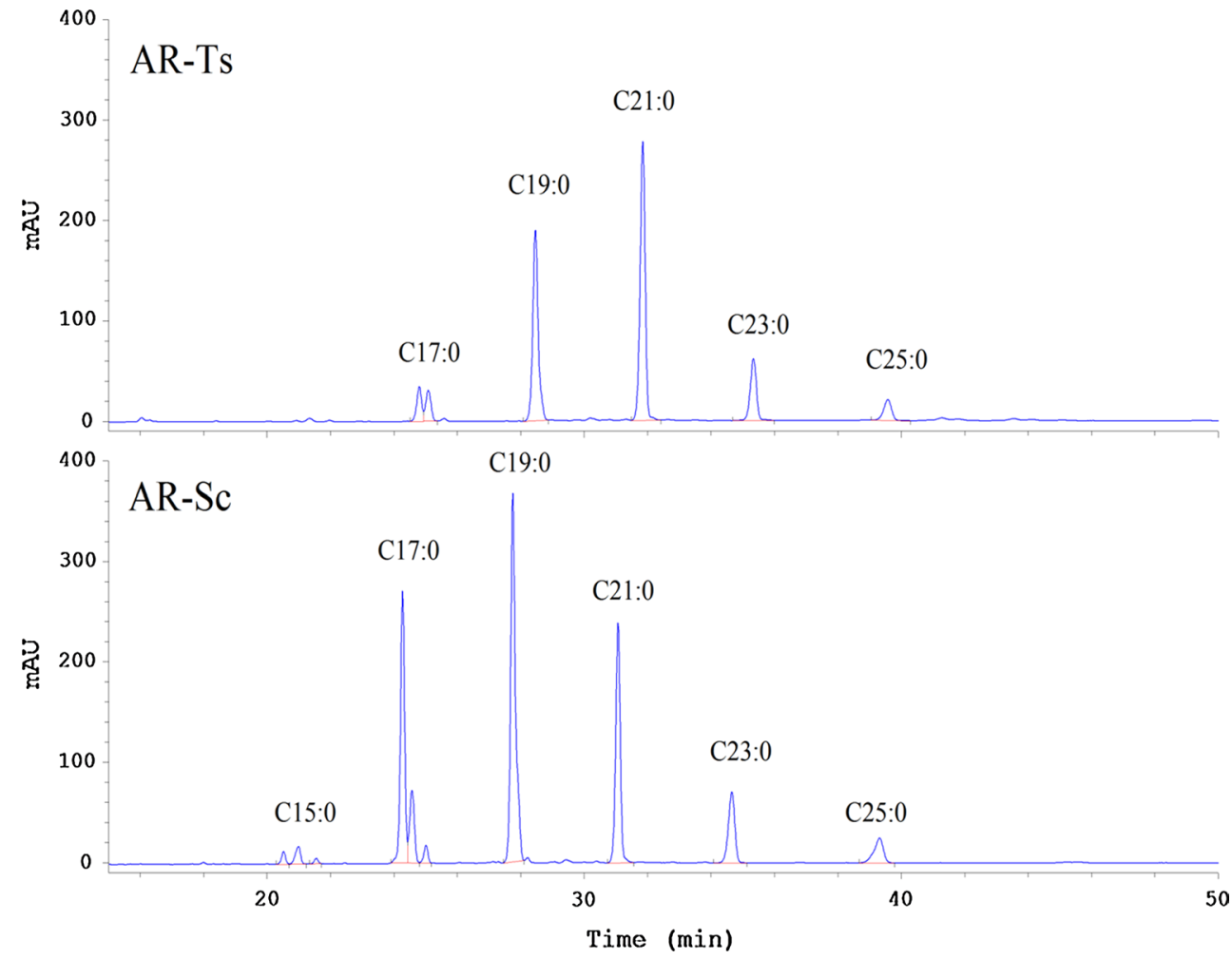

Cytotoxicity in a dose-dependent manner was observed for each tested compound and $\mathrm{IC}_{50}$ was also determined (Table 6; Fig. 6d).

Homolog with the short alkyl chain (C17:0) had the strongest inhibitory effect on the growth of mouse fibroblast cell line $\mathrm{L} 929$ expressed as $\mathrm{IC}_{50}(171 \mu \mathrm{M})$ among all tested ARs. It was followed by homolog C19:0 $(330 \mu \mathrm{M})$ and $\mathrm{C} 21: 0(511 \mu \mathrm{M})$ and then olivetol $(632 \mu \mathrm{M})$. Homologs with longer alkyl chain, C23:0 and $\mathrm{C} 25: 0$, had $\mathrm{IC}_{50}$ at levels much higher (1 965 and $2142 \mu \mathrm{M}$, respectively). The highest $\mathrm{IC}_{50}$ values and the lowest cytotoxicity were observed for orcinol $(6918 \mu \mathrm{M})$ and resorcinol $(11,043 \mu \mathrm{M})$. Cytotoxicity of AR-Ts fraction was at level between $\mathrm{C} 17: 0$ and $\mathrm{C} 19: 0$ homologs (C17:0 > AR-Ts > C19:0) (Table 6; Fig. 6d) and is probably a consequence of high content of the sum of these homologs in fraction ( $40 \%$ mass weight). For experimental point $156 \mu \mathrm{g} / \mathrm{mL}$, concentration of $\mathrm{C} 17: 0$ and $\mathrm{C} 19: 0$ homologs in AR-Ts fraction were 10 and $52 \mu \mathrm{g} / \mathrm{mL}(12$ and $55 \mu \mathrm{M})$, respectively. These concentrations were lower than cytotoxic concentration levels of single homologs. It may indicate that the presence of unsaturated homologs in fraction should be also considered. Their content is much lower, but the activity is much higher as it was observed for colon cancer cells [12]. Effective tyrosinase inhibitory concentration of ARs estimated as $10 \mu \mathrm{g} / \mathrm{mL}$ [5] was lower than concentration evaluated in our experiment as cytotoxic (Table 6; Fig. 6d).
Cytotoxic activity of resorcinol and orcinol is much lower than ARs homologs with side chain from 17 to 25 carbon atoms. Higher activity of ARs may be due to their amphiphilic properties and ability to integrate with bilayer membrane [2]. By comparing cytotoxic activity of hydroquinone and resorcinol, which are positional isomers, it was found that position of $-\mathrm{OH}$ groups in benzene ring of tested compounds is crucial for activity on mouse fibroblast cell line L929. Isomer $p$ is cytotoxic in the whole range of concentration tested while isomer $m$ only at high concentration (Table 6). $\mathrm{IC}_{50}$ for resorcinol and its 5-methyl derivative (orcinol) had the highest values. 5-n-Pentylresorcinol (olivetol) was less cytotoxic than $5-n$-heneicosylresorcinol, 5-n-nonadecylresorcinol and 5- $n$-heptadecylresorcinol (C21:0, C19:0 and C17:0). Thus, activity of ARs-related compounds increases with carbon number at $-\mathrm{R}$ but is lower than homologs with 17-21 carbon atoms in alkyl chain.

Based on results from Table 6, increasing length of the ARs alkyl chain is diminishing the cytotoxic activity which is in agreement with results from Zhu and co-workers studies [6, 7] where alkylresorcinols were evaluated for growth inhibition of human colon cancer cell lines HCT-116 and HT-29. IC $_{50}$ values of ARs in our study are two, three or more times higher than values reported for these compounds by $\mathrm{Zhu}$ et al. [6]. Higher $\mathrm{IC}_{50}$ values to normal than to cancer cells are favorable features of possible candidates for future therapeutic agents and food ingredients to prevent the process of carcinogenesis. 


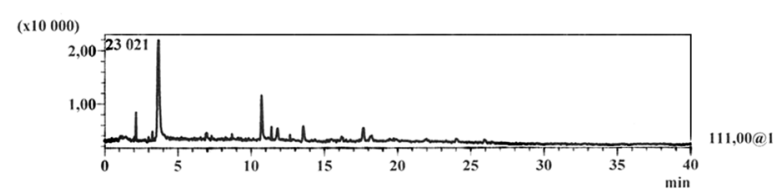

(x100 000)
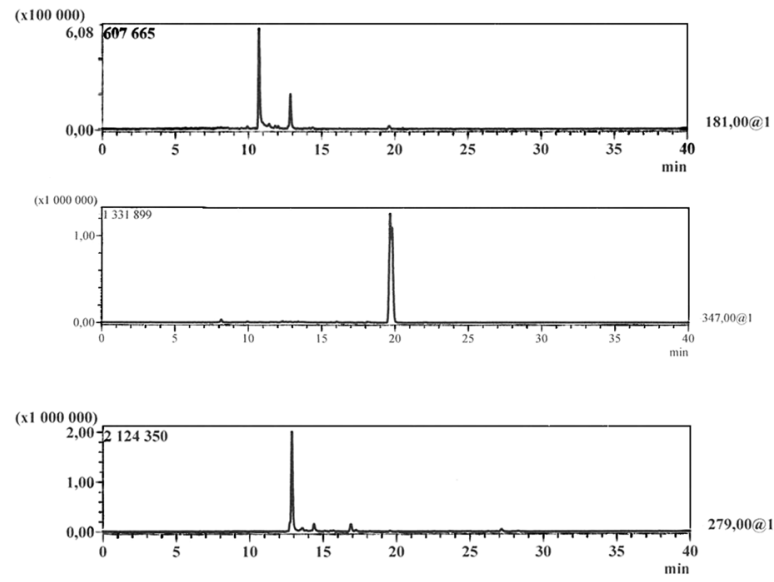
$279,00 @ 1$
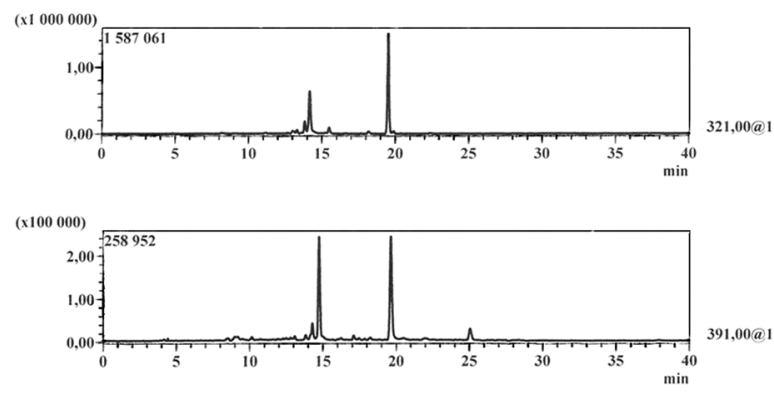
391,00@1
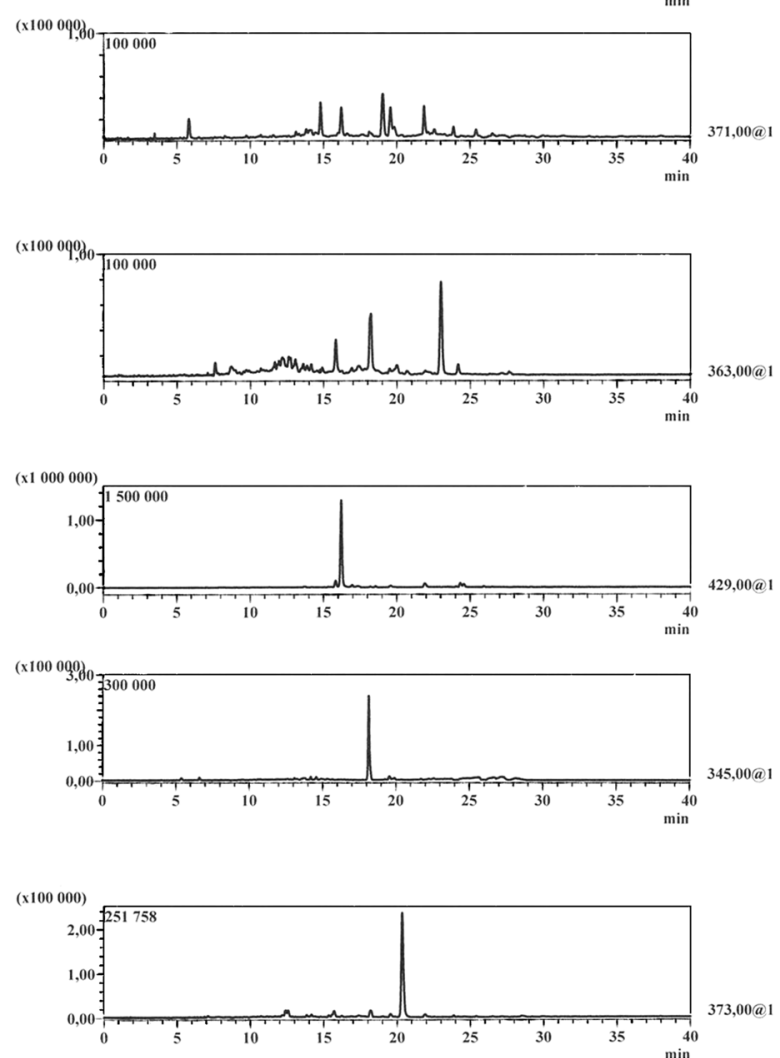
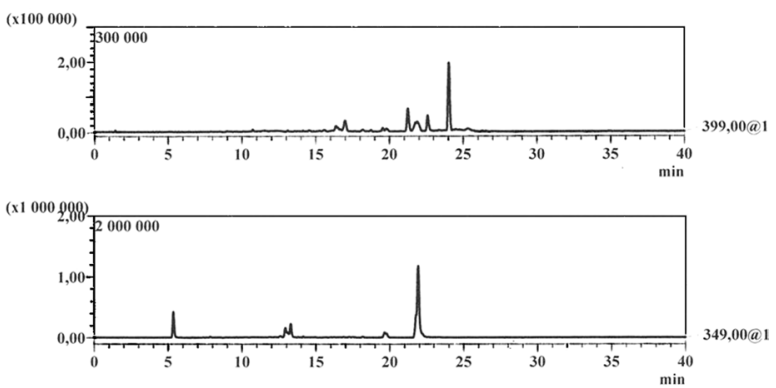

(x100 000)
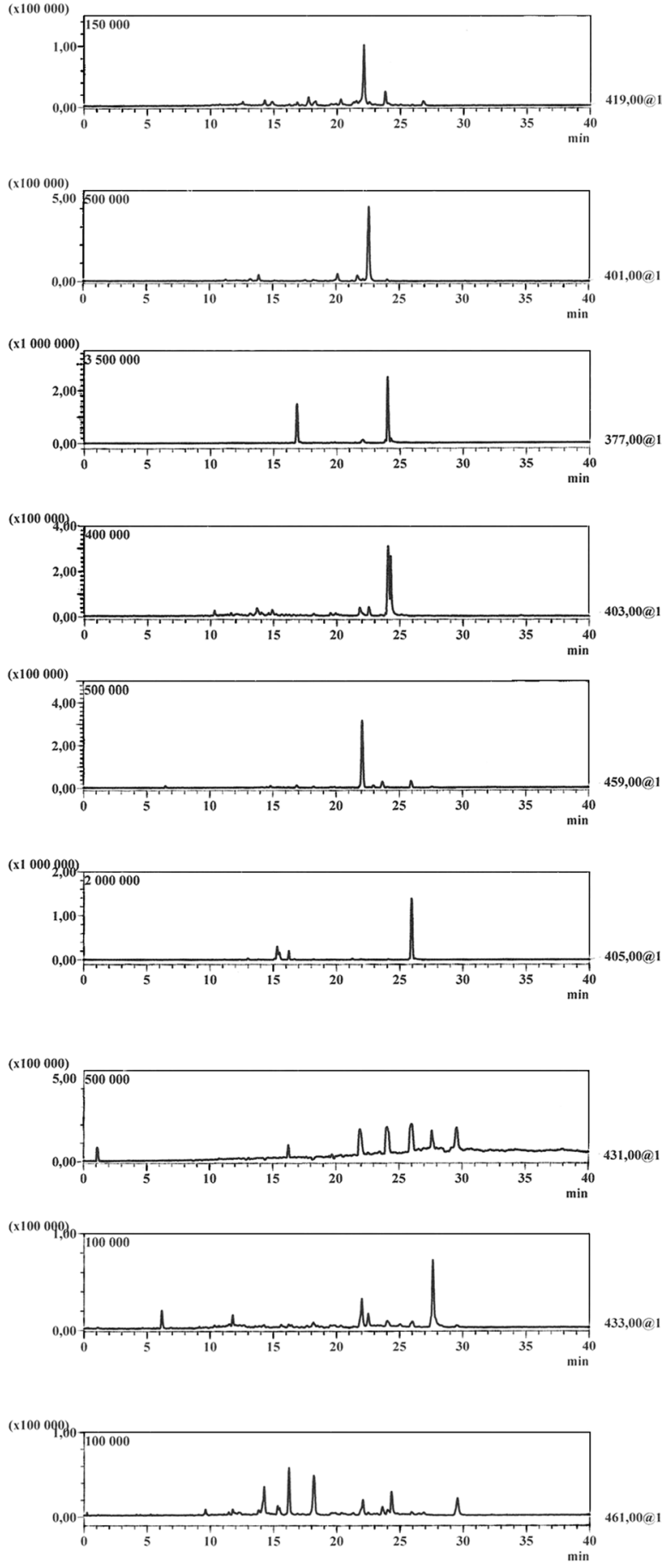

Fig. 5 UHPLC-ESI-MS spectra of alkylresorcinols protonated pseudomolecular ions detected in AR-Ts fraction conducted in the single ion monitoring mode (SIM) 


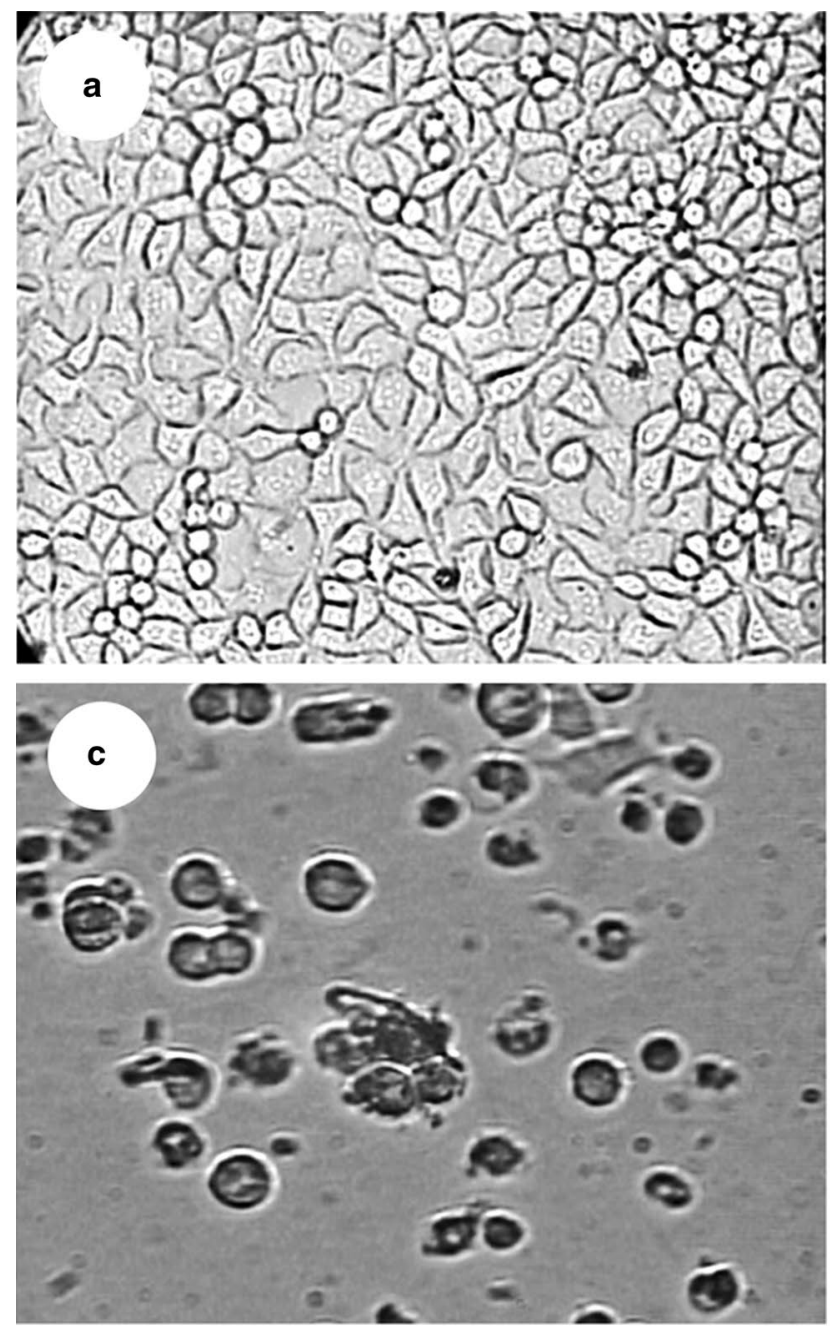

Fig. 6 a Mouse fibroblast cell line L929 that illustrates control. b Mouse fibroblast cell line L929 that illustrates non-toxic effects of tested compounds. c Mouse fibroblast cell line L929 that illustrates toxic effects of tested compounds. d Dose-response curves

This is the first time that cytotoxicity of C17:0 to C25:0 alkylresorcinol homologs was evaluated on normal cell line. We observed a structure-cytotoxicity relationship of tested compounds expressed as carbon atom number in side chain and $\log \mathrm{IC}_{50}$, respectively $(r=0.965$, Fig. 7). This relationship is as follows: hydroquinone $\gg \mathrm{C} 17: 0>\mathrm{C} 19: 0>\mathrm{C} 21: 0>$ olivetol $>\mathrm{C} 23: 0$ and $\mathrm{C} 25: 0 \gg$ orcinol $>$ resorcinol and is similar to relationship reported by Arisawa et al. [16] for shorter homologs and their cytotoxic effect on oral carcinoma $\mathrm{KB}$ cells (C13:0 > C15:0 > C11:0 > C9:0 and C17:0 > C7:0 > olivetol). Unfortunately, we were not able to isolate homolog C15:0 because of low amount in bran, but its $\mathrm{IC}_{50}$ was calculated $(152 \mu \mathrm{M})$ from quadratic equation determined experimentally on the base of our results for resorcinol

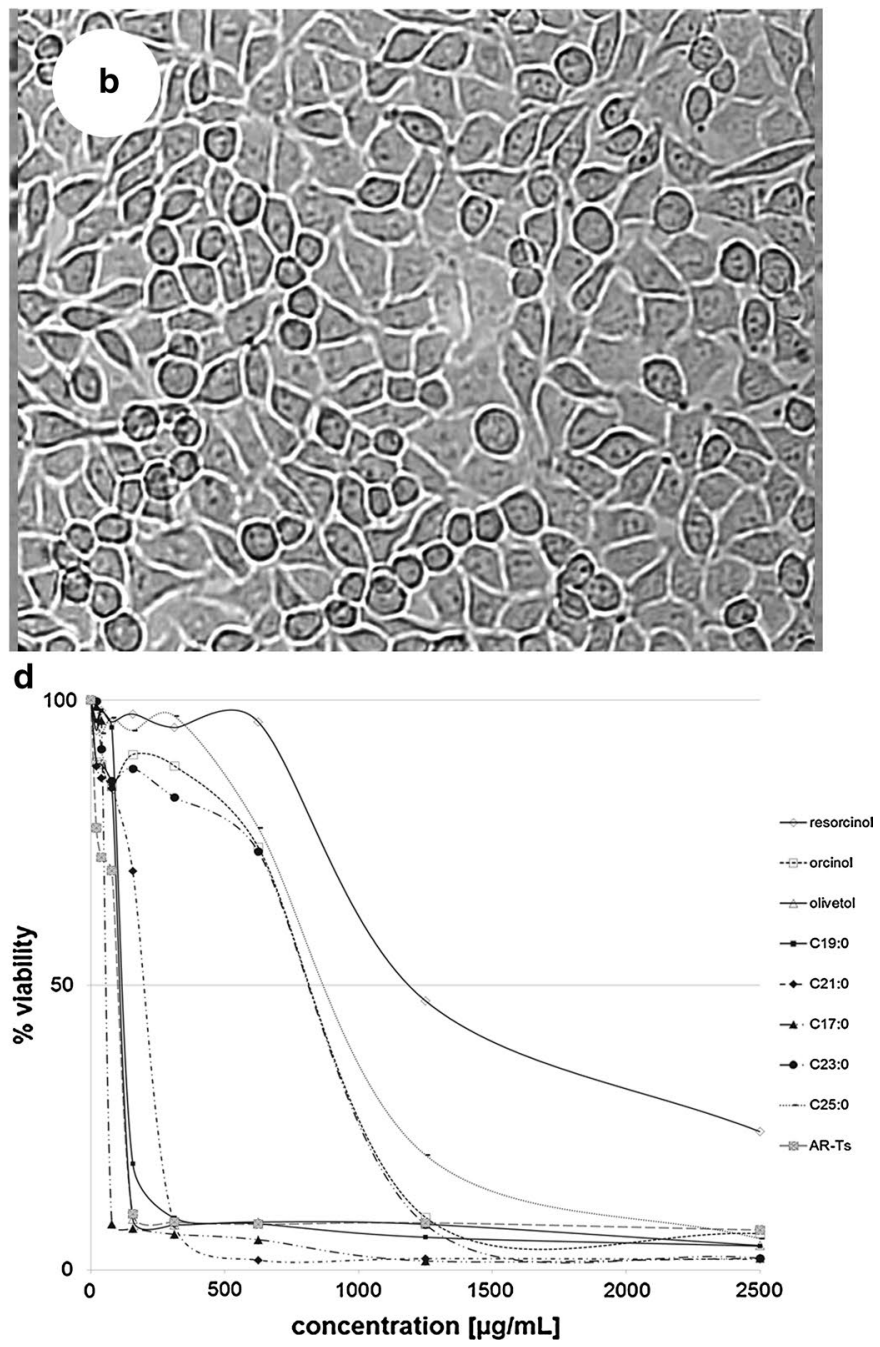

for alkylresorcinols and structurally related compounds. Response is expressed as \% viability of mouse fibroblast cell line L929 after 72-h contact with tested substances

derivatives (Fig. 7). This value is comparable with $\mathrm{IC}_{50}$ obtained for C17:0 homolog determined experimentally.

The median plasma total ARs concentrations among participants of European Prospective Investigation into Cancer and Nutrition (EPIC) cohort were assessed to be $41 \mathrm{nM}$ in samples drawn from fasting participants in Scandinavian population which is known to consume high amounts of whole-grain food and below $23 \mathrm{nM}$ in those of participants from the Mediterranean countries [17]. The levels of cytotoxicity of individual homologs and AR-Ts indicated in this study exceed at least $10^{4}$ times the concentration of ARs identified in human plasma, and under conditions of regular diet are not possible to obtain. However, ARs can be accumulated in human adipose tissue. The concentration was in range from 0 to $1.5 \mu \mathrm{g} / \mathrm{g}$ and was correlated with long-term 
Fig. 7 Relationship between carbon atoms in side chain of ARs and related compounds and cytotoxicity to mouse fibroblast cell line $\mathrm{L} 929\left(\right.$ as $\left.\log \mathrm{IC}_{50}\right)$

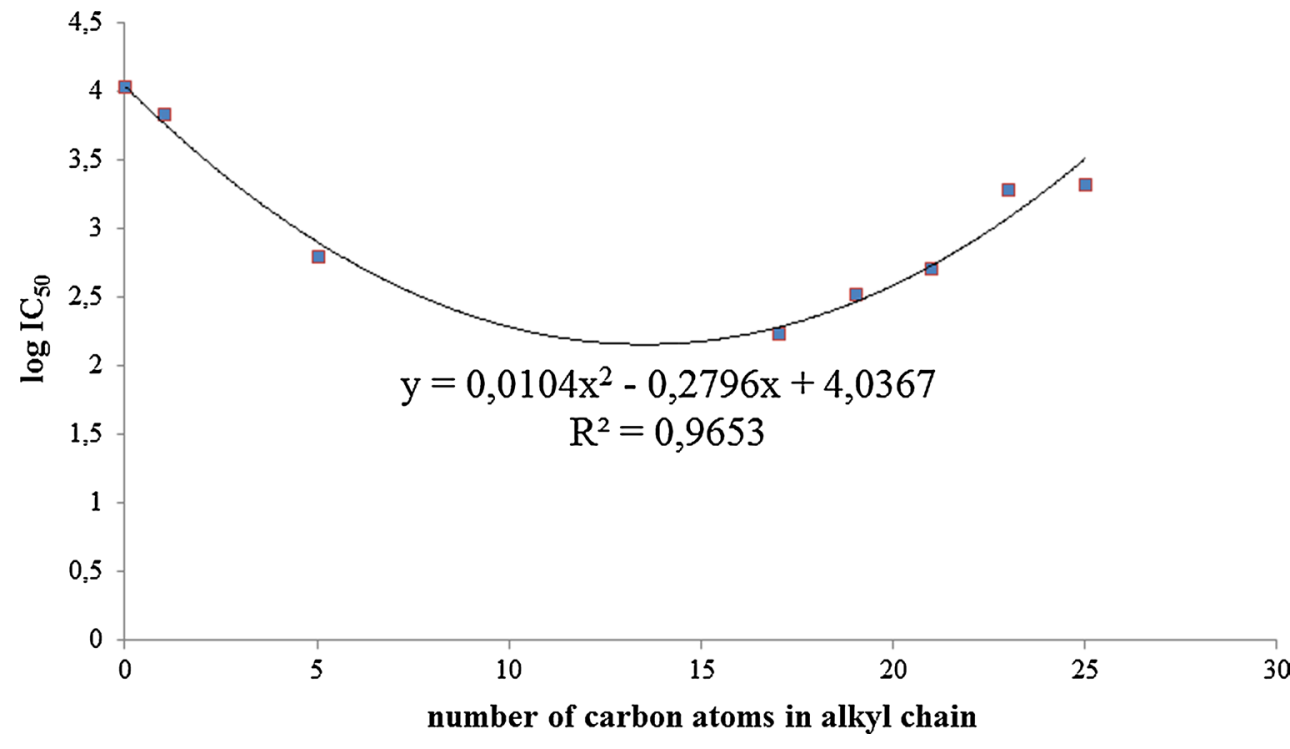

Table 6 Cytotoxicity of ARs homologs, fraction and related compounds on mouse fibroblast cell line L929

\begin{tabular}{|c|c|c|c|c|c|c|c|c|c|c|c|}
\hline \multirow[t]{2}{*}{ Compound } & \multirow[t]{2}{*}{ Molecular weight $(\mathrm{g} / \mathrm{mol})$} & \multicolumn{2}{|c|}{$\mathrm{IC}_{50}$ (MTT assay) } & \multicolumn{8}{|c|}{ Concentration in $\mu \mathrm{g} / \mathrm{mL}$ (microscopic observation) } \\
\hline & & $(\mu \mathrm{g} / \mathrm{mL})$ & $(\mu \mathrm{M})$ & 19.5 & 39 & 78 & 156 & 312 & 625 & 1250 & 2500 \\
\hline Blank $^{\mathrm{a}}$ & & - & - & $\mathrm{n}$ & $\mathrm{n}$ & $\mathrm{n}$ & $\mathrm{n}$ & $\mathrm{n}$ & $\mathrm{n}$ & $\mathrm{n}$ & $\mathrm{n}$ \\
\hline Hydroquinone $^{\mathrm{b}}$ & 110 & $<19.5$ & $<177$ & $\mathrm{t}$ & $\mathrm{t}$ & $\mathrm{t}$ & $\mathrm{t}$ & $\mathrm{t}$ & $\mathrm{t}$ & $\mathrm{t}$ & $\mathrm{t}$ \\
\hline Resorcinol & 110 & 1215 & 11,043 & $\mathrm{n}$ & $\mathrm{n}$ & $\mathrm{n}$ & $\mathrm{n}$ & $\mathrm{n}$ & $\mathrm{n}$ & $\mathrm{t}$ & $\mathrm{t}$ \\
\hline Orcinol C1:0 & 124 & 858 & 6918 & $\mathrm{n}$ & $\mathrm{n}$ & $\mathrm{n}$ & $\mathrm{n}$ & $\mathrm{n}$ & $\mathrm{n}$ & $\mathrm{t}$ & $\mathrm{t}$ \\
\hline Olivetol C5:0 & 180 & 114 & 632 & $\mathrm{n}$ & $\mathrm{n}$ & $\mathrm{n}$ & $\mathrm{t}$ & $\mathrm{t}$ & $\mathrm{t}$ & $\mathrm{t}$ & $\mathrm{t}$ \\
\hline Homolog C 17:0 & 348 & 59 & 171 & $\mathrm{n}$ & $\mathrm{n}$ & $\mathrm{t}$ & $\mathrm{t}$ & $\mathrm{t}$ & $\mathrm{t}$ & $\mathrm{t}$ & $\mathrm{t}$ \\
\hline Homolog C 19:0 & 376 & 124 & 330 & $\mathrm{n}$ & $\mathrm{n}$ & $\mathrm{n}$ & $\mathrm{t}$ & $\mathrm{t}$ & $\mathrm{t}$ & $\mathrm{t}$ & $\mathrm{t}$ \\
\hline Homolog C 21:0 & 404 & 206 & 511 & $\mathrm{n}$ & $\mathrm{n}$ & $\mathrm{n}$ & $\mathrm{n}$ & $\mathrm{t}$ & $\mathrm{t}$ & $\mathrm{t}$ & $\mathrm{t}$ \\
\hline homolog C 23:0 & 432 & 849 & 1965 & $\mathrm{n}$ & $\mathrm{n}$ & $\mathrm{n}$ & $\mathrm{n}$ & $\mathrm{n}$ & $\mathrm{n}$ & $\mathrm{t}$ & $\mathrm{t}$ \\
\hline Homolog C 25:0 & 460 & 925 & 2142 & $\mathrm{n}$ & $\mathrm{n}$ & $\mathrm{n}$ & $\mathrm{n}$ & $\mathrm{n}$ & $\mathrm{n}$ & $\mathrm{t}$ & $\mathrm{t}$ \\
\hline AR-Ts fraction & & 104 & - & $\mathrm{n}$ & $\mathrm{n}$ & $\mathrm{n} / \mathrm{t}$ & $\mathrm{t}$ & $\mathrm{t}$ & $\mathrm{t}$ & $\mathrm{t}$ & $\mathrm{t}$ \\
\hline
\end{tabular}

a Serial dilution of DMSO in MEM (without tested compound)

b Positive control

intake of whole-grain food [18]. It means that cytotoxicity $\mathrm{IC}_{50}$ values of $\mathrm{C} 17: 0$ homolog, potentially the most cytotoxic component, and AR-Ts are more than 50 times higher than concentration in adipose tissue. However, high local concentrations of ARs from fortified food or skin-lightening products are possible to arise and need to be kept in mind.

ARs could be potentially used as food additive in order to prevent food browning or to fortification of bread and breakfast cereals, or as ingredients of diet supplements which could help in type 2 diabetes prevention. For such use of ARs, it is necessary to establish safe concentrations and the ADI (acceptable day intake) for them. In the present study, alkylresorcinols isolated from spelt and rye bran exhibited cytotoxicity lower than hydroquinone but higher than resorcinol on normal cells. The highest cytotoxic activity among isolated homologs was evaluated for C17:0 which level in bran, especially spelt, is low. This study extends our knowledge about potential safety of use of alkylresorcinols in food, cosmetic or pharmaceutical industry.

Acknowledgements Authors greatly acknowledged Maciej Wlodarczyk for support in NMR analysis.

Funding This work was partly supported by the research fellowship for Izabela Biskup from European Social Fund, Human Capital, National Cohesion Strategy under Development Program of Wroclaw Medical University [UDA-POKL.04.01.01-00-010/08-00] and 
internal grant of Wroclaw Medical University for Young Scientists under Grant [Pbmn 128].

\section{Compliance with ethical standards}

Conflict of interest Authors declare no conflict of interest.

Human and animal rights This article does not contain any studies with human or animal subjects.

Open Access This article is distributed under the terms of the Creative Commons Attribution 4.0 International License (http://creativecommons.org/licenses/by/4.0/), which permits unrestricted use, distribution, and reproduction in any medium, provided you give appropriate credit to the original author(s) and the source, provide a link to the Creative Commons license, and indicate if changes were made.

\section{References}

1. Kulawinek M, Kozubek A (2008) Quantitative determination of alkylresorcinols in cereal grains: independence of the length of the aliphatic side chain. J Food Lipids 15(2):251-262

2. Kozubek A, Tyman JHP (1999) Resorcinolic lipids, the natural non-isoprenoid phenolic amphiphiles and their biological activity. Chem Rev 99(1):1-26

3. Gąsiorowski K, Brokos B, Kulma A, Ogorzałek A, Skórkowska $\mathrm{K}$ (2001) Impact of four antimutagens on apoptosis in genotoxically damaged lymphocytes in vitro. Cell Mol Biol Lett 6(3):649-675

4. Tu J, Chen J, Zhu S, Zhang C, Chen H, Liu Y (2013) Inhibition of wheat bran and it's active components on $\alpha$-glucosidase in vitro. Pharmacogn Mag 9(36):309-314

5. Rebolleda S, Sanz MT, Benito JM, Beltrán S, Escudero I, González San-José ML (2015) Formulation and characterisation of wheat bran oil-in-water nanoemulsions. Food Chem 167:16-23

6. Zhu Y, Conklin DR, Chen H, Wang L, Sang S (2011) 5-Alk(en) ylresorcinols as the major active components in wheat bran inhibit human colon cancer cell growth. Bioorg Med Chem 19(13):3973-3982
7. Zhu Y, Soroka DN, Sang S (2012) Synthesis and inhibitory activities against colon cancer cell growth and proteasome of alkylresorcinols. J Agric Food Chem 60(35):8624-8631

8. Athukorala Y, Hosseinian FS, Mazza G (2010) Extraction and fractionation of alkylresorcinols from triticale bran by two-step supercritical carbon dioxide. LWT-Food Sci Tech 43(4):660-665

9. Dey ES, Mikhailopulo K (2009) A food grade approach for the isolation of major alkylresorcinols (ARs) from rye bran applying tailored supercritical carbon dioxide $\left(\mathrm{scCO}_{2}\right)$ extraction combined with HPLC. J Supercrit Fluids 51(2):167-173

10. Knödler M, Kaiser A, Carle R, Schieber A (2008) Profiling of alk(en)ylresorcinols in cereals by HPLC-DAD-APcI-MS ${ }^{\mathrm{n}}$. Anal Bioanal Chem 391(1):221-228

11. Żarnowska ED, Żarnowski R, Kozubek A (2000) Alkylresorcinols in fruit pulp and leaves of Ginkgo biloba L. Z Naturforsch 55c:881-885

12. Al-Mekhlafi NA, Shaari K, Abas F, Kneer R, Jeyaraj EJ, Stanslas J, Yamamoto N, Honda T, Lajis NH (2012) Alkenylresorcinols and cytotoxic activity of the constituents isolated from Labisia pumila. Phytochem 80:42-49

13. Bobere N, Podjava A, Meija L, Jākobsone I (2013) Content of alkylresorcinols in cereals grown in Latvia determined by high performance liquid chromatography with UV. Proc Latv Acad Sci B Nat Exact Appl Sci 67(4-5):389-393

14. Parikka K, Wähälä K (2009) An expedient synthesis of 5-n-alkylresorcinols and novel 5-n-alkylresorcinol haptens. Beilstein $\mathrm{J}$ Org Chem. doi:10.3762/bjoc.5.22

15. Tse TW (2010) Hydroquinone for skin lightening: safety profile, duration of use and when should we stop? J Dermatological Treat 21(5):272-275

16. Arisawa M, Ohmura K, Kobayashi A, Morita N (1989) A cytotoxic constituent of Lysimachia Japonica THUNB. (Primulaceae) and the structure-activity relationships of related compounds. Chem Pharm Bull 37:2431-2434

17. Kyrø C, Olsen A, Bueno-de-Mesquita HBA, Skeie G, Loft S, Åman P, Leenders M, Dik VK, Siersema PD, Pischon T et al (2014) Plasma alkylresorcinol concentrations, biomarkers of whole-grain wheat and rye intake, in the European Prospective Investigation into Cancer and Nutrition (EPIC) cohort. Brit J Nutr 111(10):1881-1890

18. Jansson E, Landberg R, Kamal-Eldin A, Wolk A, Vessby B, Aman $P$ (2010) Presence of alkylresorcinols, potential whole grain biomarkers, in human adipose tissue. Brit J Nutr 104(5):633-636 